\title{
THE IMPACT OF INTERGOVERNMENTAL TRANSFERS ON THE FINANCIAL SECURITY OF THE CONSTITUENT ENTITIES OF THE RUSSIAN FEDERATION
}

\author{
Roman M. Kotov ${ }^{1}$ \\ Nuriya M. Chernysheva ${ }^{2}$
}

\begin{abstract}
The research focuses on the mechanism of inter-budget transfers in the budget system of the Kemerovo Oblast. The evolution of inter-budgetary relations of the RF is discussed, models of separating the powers are given, implementation of the regional budget and that of municipalities are analyzed, and the role of inter-budget transfers in leveling budgetary provision is revealed.
\end{abstract} The research aims to identify promising areas for strengthening regional and local budgets in the Kemerovo Oblast. The crucial method is to analyze the structure and dynamics of the budgets of the Kemerovo Oblast and its municipalities, as well as to look into inter-budget transfers. The dynamics and structure of intergovernmental transfers are investigated using economic and statistical analysis. Based on the results, an assessment is made of the existing model for implementing the mechanism of inter-budget transfers, the directions for reforming this mechanism are stated, and sources of increasing the revenue side of budgets are identified to reduce the dependence of the regional budget on the federal one.

Keywords: intergovernmental transfers, budget security, budget, subsidies

\section{Introduction}

Uniform development of all entities is a fundamental issue of the government; this issue can be solved through a system of effective intergovernmental regulation, a system which takes into account the national characteristics of the state.

Inter-budget transfers are an important feature of the economic policy of any federation. The most important business case for intergovernmental transfers is achieving horizontal

\footnotetext{
${ }^{1}$ Kemerovo State University, 6 Krasnaya Str., Kemerovo, Russia, 650000

${ }^{2}$ Kemerovo State University, 6 Krasnaya Str., Kemerovo, Russia, 65000
} 
equality.

The principle of horizontal equality is due to the argument that an equitable distribution of resources will eliminate the scarcity of resources that arises in subnational units. In the absence of a horizontal redistribution of resources, resource-deficient regions will struggle to eliminate inter-regional differences in economic growth and economic development.

Both in Russia and worldwide, the fundamental organizational goal of such regulation is to equalize the level of socio-economic development of the country's subjects. In Russia the main method that evens out budget financing is the distribution of federal transfers among the regions.

At the present stage of development of Russia, the problem of optimal formation and distribution of budget funds is urgent. The budgets of local governments are increasingly dependent on the federal budget; the state cannot fully satisfy the interests of all the entities in the field of financial support for national and regional projects.

With the current political and economic development of the country, subsidizing vital sectors, such as agriculture, is necessary. This area should be on the list of priority tasks to ensure Russia's food security in the context of economic sanctions. The amount of subsidies to rural areas often depends on external phenomena such as weather that are not controlled by local entities and can affect decentralization de facto, affecting the financial capacities of local authorities. The consequences of climatic cataclysms cause fluctuations in income from agriculture, affect the collection of revenues of local authorities and, in turn, stimulate further income received by local authorities through transfers from the central government [26]

These are factors impeding the development of the financial system of Russia; therefore, the problems of interbudgetary relations in the Russian Federation are increasingly relevant.

The present research aims to briefly review the latest achievements in the state policy of financing the regions, and to provide details and an assessment of the financing of the Kemerovo Oblast.

\section{Materials and Methods}

Currently, the economic development of Russia is characterized by dynamic organizational and structural 
changes in public finance. Improving intergovernmental relations in the framework of the budget system reform are an important part of state policy in terms of financial relations. Balancing budgets at all levels is the basis of the ongoing economic development. To achieve balance, it is necessary to level the 'lower' budgets with the help of inter-budget transfers. Transfers provision is regulated by Chapter 16 of the Budget Code of the RF.

The evolutionary development of intergovernmental relations has five stages:

1) At the first stage (1991-1993), the basic tenets of federalism in the Russian Federation were formed. The distinguishing feature of inter-budgetary relations was the strengthening of centrifugal trends. Taxes assigned to the corresponding levels of the budget system of Russia were the sources of budget revenues. By Decree No. 2268 of the President of the Russian Federation of December 22, 1993, the Federal Fund for the Financial Support of Regions was established to implement the interbudgetary alignment [10];

2) The second stage (1994-1998) was legitimate decentralization. A feature of the period is the 'non- monetary' execution of budgets. The budgetary provision of the regions is formed on the assessment of tax revenues and expenditure items of the budget $[10,12]$;

3) The third stage (1998-2000) was characterized by new improvements of organizational and legal support of intergovernmental relations. In interbudgetary interaction, there was a tendency towards centralization. The financial security of state entities was determined through an assessment of the budget expenditures index and the tax potential index [10];

4) The fourth stage (2001-2005) was characterized by strengthening centralization. A system of borrowing functioned at the regional level. Authorities of the constituent entities of the RF, especially local self-government, were vested with limited formal powers to form their own income and expenses $[10,5]$;

5) At the fifth stage (2005present), the local level of the budget system in intergovernmental relations is of most interest [10].

Russian and foreign authors consider various models of intergovernmental relations. 
Richard M. Bird and Michael Smart, in their article 'Inter-Budget Transfers: International Lessons for Developing Countries,' addressing the main problems of developing government transfers, conclude that no simple, uniform transfer scheme is universally acceptable, yet the world's experience clearly shows that to ensure the effective provision of services, the transfer of federal funds should be designed in such way that the entities receiving them have a clear mandate, adequate resources, sufficient flexibility for decision-making and responsibility for results [27].

The differentiation of interbudgetary relations is directly influenced by the specific feature of the construction of budget systems in each individual state, and, in addition, the form of movement of cash flows between budget levels. Thus, the models are divided into decentralized and cooperative [12].

The cooperative model is most widespread in world practice, including Russia. Its distinguishing features are: close cooperation in inter-budgetary relations at the central and regional levels of government; high degree of centralization of regional financial management by the government, as well as limited independence of regional authorities. An important role in this model is represented by transfers which include various forms of intergovernmental regulation [12].

Inter-budget transfers can be classified by their types: equalizing (unconditional) and target (conditional).

In the Russian Federation, subsidies can be classified as unconditional intergovernmental transfers, and subsidies and subventions as conditional.

An essential aspect in forming intergovernmental relations is the separation of powers: revenue and expenditure. In world economic practice, there are several basic models of separation of powers:

1) In the first model, the federal authorities have a clear-cut range of exclusive powers, and the remaining powers are distributed between territories (states);

2) In the second model, there are two different groups of powers respectively, only federal or sub-federal;

3) The third model is characterized by the following powers: state, federal subjects and series of combined powers; 
4) In the fourth model, an exhaustive list of powers is assigned to the federation and a joint list is the responsibility of the state and its subjects [12].

The decree No. 204 of May 7, 2018of the President of the Russian Federation stipulates that "in the field of inter-budget relations, it is necessary to reorient targeted inter-budget transfers and to review the level of co-financing from the federal budget" [1].

\section{Results and Discussion}

Inter-budget transfers are a mechanism that ensures equilibrium and balance of various levels of government, and are a component of budget regulation of the country's economy.
704

The mechanism of inter-budget transfers, firstly, corrects vertical imbalances, i.e. eliminates the discrepancy between the expenditure side of regional and local budgets and the share of their financing (limited budgetary liability) which is assigned to this budget; second, it is meant to equalize the level of using public services in different regions.

Do intergovernmental transfers reduce revenues collected by local governments? According to Takaaki Masaki, government transfers 'crowd out' local revenues [28].

A limited share of tax revenues to local budgets is offset by transfers from the federal and regional budgets, the share of which is increasing from year to year.

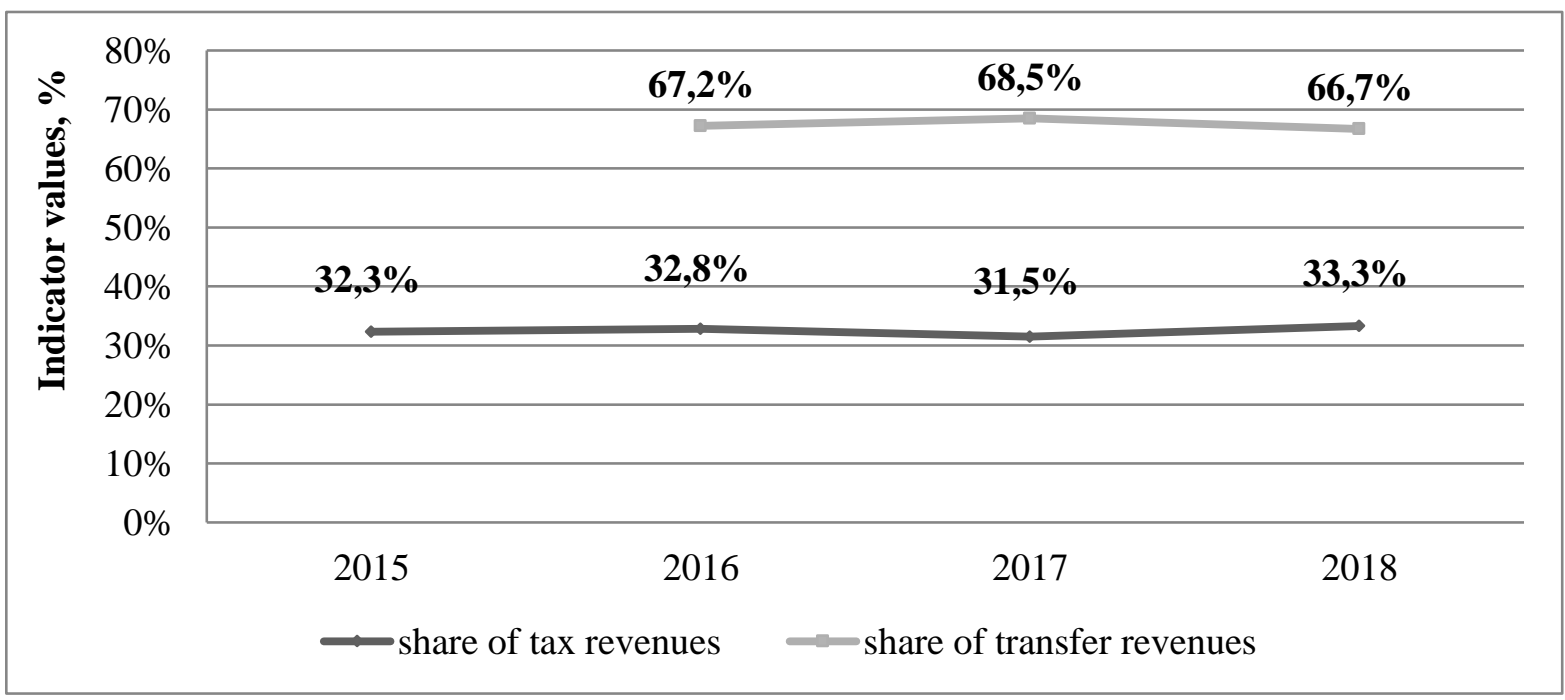


Figure 1. Changes in the share of tax revenues and transfer payments in the budget of the Kemerovo Oblast

Source: compiled by the author based on [13].

The data presented in Figure 1 indicate steady trends in the formation of the local budget in the Kemerovo Oblast, mainly due to the high share of transfer revenues from the federal and regional budgets with a relatively small share of tax revenues that form the revenues of local budgets.

This reveals the shortcomings of the existing mechanism of interbudgetary relations of economic regulation, and the low interest of local governments in the formation and consolidation of local budgets.

During 2015-2019, the most significant volumes of financing were directed to the cities of Kemerovo and Novokuznetsk.

These budget transfers are aimed at equalizing regional disparities in the assistance to local government budgets.

Transfers to Kemerovo and Novokuznetsk are associated with the special status of the cities and are aimed at developing the infrastructure and public transport, at solving socio-economic problems related to medicine, education, culture, etc.

According to the Ministry of Finance of the RF which monitored the implementation of local budgets for 20152018, the Kemerovo Oblast belongs to the constituent entities of the Russian Federation with a minimum share of tax revenues in own revenues of local budgets, namely, this indicator was fixed at $32.3 \%$ in 2015 with the average value of $44.2 \%$ in the country; $32.8 \%$ in 2016 with the national average of $44.8 \%$; $31.5 \%$ in 2017 with the national average of $44.8 \%$, similar to $2016 ; 33.3 \%$ in 2018 with the national average of $44.1 \%$ [6-9]. The statistics show a slight increase in the share of tax revenues in the budget of the Kemerovo Oblast. However, the growth rate is insufficient to approach the average value, 
which is a negative factor in the formation of Kemerovo city budget revenues for 2015the revenue side of the budget. 2019.

The authors carried out a structural analysis of tax revenues in the context of

Table 1. The structure of tax deductions to the budget of the city of Kemerovo for the period $2015-2019$

\begin{tabular}{|c|c|c|c|c|c|}
\hline \multirow{2}{*}{$\begin{array}{c}\text { Billing period, } \\
\text { year }\end{array}$} & \multicolumn{4}{|c|}{ tax deductions, \% } & Volume of \\
\cline { 2 - 5 } & Income tax & Land tax & $\begin{array}{c}\text { Unified tax } \\
\text { on imputed } \\
\text { income }\end{array}$ & Other taxes & $\begin{array}{c}\text { deductions, } \\
\text { mil. RUR. }\end{array}$ \\
\hline 2015 & 63.7 & 19.0 & 10.5 & 6.8 & 4093.9 \\
\hline 2016 & 62.7 & 20.0 & 8.8 & 8.5 & 4120.1 \\
\hline 2017 & 68.8 & 15.0 & 7.5 & 8.9 & 4517.8 \\
\hline 2018 & 64.6 & 11.8 & 5.8 & 8.1 & 5705.8 \\
\hline 2019 & 64.1 & 11.7 & - & 14.1 & 5681.9 \\
\hline
\end{tabular}

Source: compiled by the author based on [Erro! Fonte de referência não encontrada.].

Table 1 shows that the main tax that forms the budget of the city of Kemerovo is the personal income tax. The share of this tax was the largest in $2017-68.8 \%$, the increase in the share over the entire period is very insignificant $-0.6 \%$. The share of land tax and unified tax on imputed income decreased throughout the entire period; the share of other taxes, on the contrary, increased noticeably -2.1 times. Thus, over the analyzed period, the volume of revenues from levied taxes increased by $38.8 \%$. Nevertheless, expenditure items are not fully covered, and therefore the budget deficit remains.
In addition to cash flows from tax revenues, the budget revenue is generated from other sources. The share of non-tax revenues has a stable downward trend; tax revenues are not enough, which necessitates the attraction of inter-budget transfers as the main source of generating budget revenue.

The main intergovernmental transfers are subventions, dotations, subsidies and other transfers. Figure 2 shows the distribution of types of inter-budget transfers in the revenue part of the budget (based on the reports on the budget execution of the city of Kemerovo). 


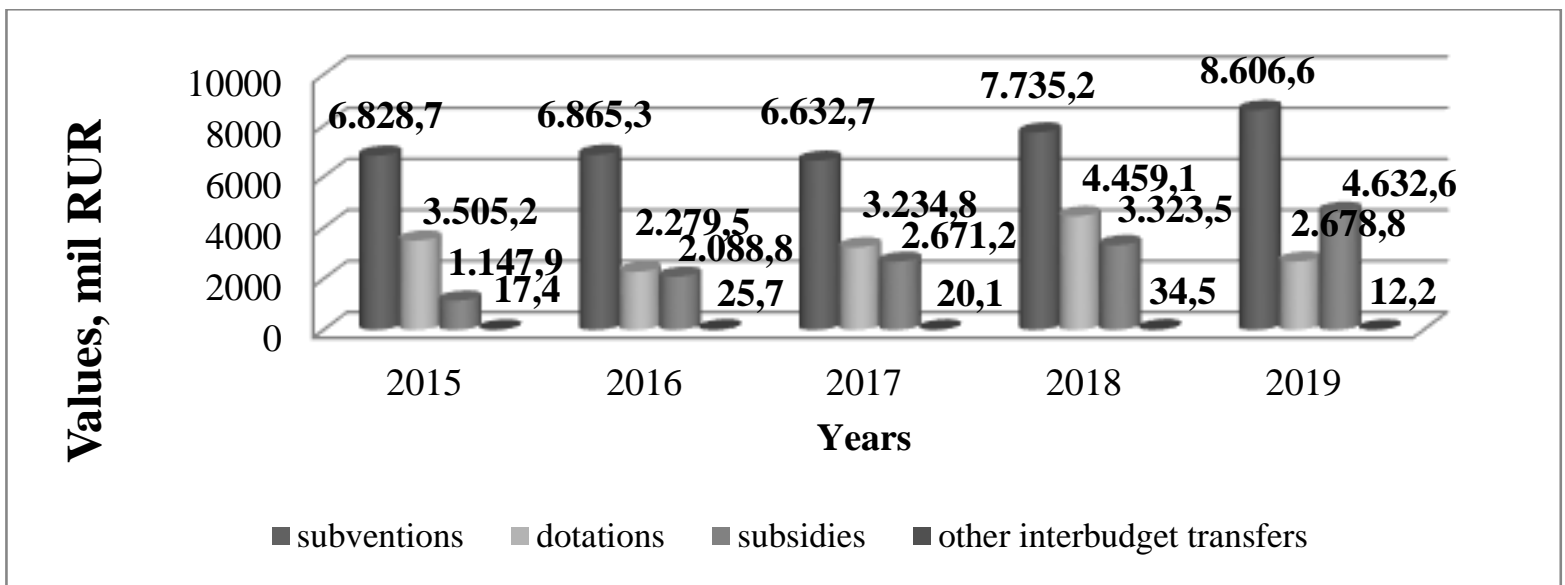

Figure 2. Revenues of intergovernmental transfers to the budget of the city of Kemerovo for 2015-2019.

Source: compiled by the author based on [Erro! Fonte de referência não encontrada., Erro! Fonte de referência não encontrada.-Erro! Fonte de referência não encontrada.].

Figure 2 shows that inter-budget transfers in the budget revenues are represented mainly by subventions. The amount of subventions tended to slightly decrease in 2016-2017 (by 3.7\%), and from 2017 to 2019 year it increased (from 6.632,7 mil. RUR to 8.606,6 mil. RUR, or 29.8\%). In fractional terms, subventions accounted for $59 \%$ and $69.9 \%$ in 2015 and 2019 of the reporting period, respectively.

Dotations occupy the second place in the structure of transfers. Their dynamics is uneven: in 2015-2016 a decrease by $35 \%$ was observed; in 2016-2018 a 1.9-times increase; in 2018-2019, a sharp decrease by $40 \%$ was observed (from 4.459,1 mil. RUR to $2.678,8$ mil. RUR). The proportion of dotations in 2015-2019 varied from $30 \%$ to $16.8 \%$.
Subsidies, which occupy the third place in the total volume of intergovernmental transfers, have a steady upward trend. If in 2015 subsidies amounted to $1.147,9$ mil. RUR, by the end of the analyzed period (in 2019) their value amounted to 4.632,6 mil. RUR.

To eliminate the differences between the provision of lower levels of the budgetary system in terms of financial equalization of the RF, subsidized transfers are provided to align budgetary levels. The Budget Code of the RF determines that "the total amount of gratuitous deductions in the form of a subsidy for equalizing the budgetary provision of the constituent entities of the Russian Federation is calculated based on the need to achieve the minimum level of estimated budgetary 
security of the constituent entities of the Russian Federation” [4].

In the Siberian Federal District for 2020 , the following values of the indicators of estimated budgetary security and the budget expenditures index are determined, on the basis of which subsidies are allocated (Table 2).

Table 2. Level parameters of estimated budgetary security and the budget expenditures index of the constituent entities of the RF in the SFD as of 2020

\begin{tabular}{|l|c|c|}
\hline \multicolumn{1}{|c|}{ Federal subjects } & estimated budgetary security & budget expenditures index \\
\hline Altai Republic & 0.690 & 1.693 \\
\hline Tuva Republic & 0.655 & 1.780 \\
\hline Republic of Khakassia & 0.730 & 1.120 \\
\hline Altai Republic & 0.687 & 0.945 \\
\hline Krasnoyarsk Krai & 1.033 & 1.345 \\
\hline Irkutsk Oblast & 0.974 & 1.157 \\
\hline Kemerovo Oblast & 0.940 & 0.941 \\
\hline Novosibirsk Oblast & 0.890 & 0.947 \\
\hline Omsk Oblast & 0.740 & 0.922 \\
\hline Tomsk Oblast & 0.760 & 1.251 \\
\hline \multicolumn{1}{|c|}{ average value in the RF } & $\mathbf{1 . 0 0 0}$ & $\mathbf{1 . 0 0 0}$ \\
\hline
\end{tabular}

Source: compiled by the author based on [Erro! Fonte de referência não encontrada.].

Table 2 shows that, in terms of estimated budgetary security, the Kemerovo Oblast occupies the third place with the value of 0.941 . The most subsidized region of the district is the Republic of Tuva (0.655).
Let us consider how the distribution of intergovernmental transfers was carried out to equalize the level of budgetary provision in the Kemerovo Oblast in 20162019.

Table 3. Distribution of dotations deductions for leveling the budget provision of the Kemerovo Oblast for 2016-2019 
709

\begin{tabular}{|c|c|c|c|c|}
\hline \multirow{2}{*}{ Indicator } & \multicolumn{4}{|c|}{ Year } \\
\hline & 2016 & 2017 & 2018 & 2019 \\
\hline $\begin{array}{l}\text { 1. Resident population, thousand } \\
\text { people }\end{array}$ & 2725.0 & 2717.6 & 2762.2 & 2717.6 \\
\hline Total number in the RF & $146,267.3$ & $146,544.7$ & $146,544.7$ & $146,544.7$ \\
\hline 2. Tax potential index & 0.711 & 0.720 & 0.718 & 0.715 \\
\hline Total value in the $\mathrm{RF}$ & 1.000 & 1.000 & 1.000 & 1.000 \\
\hline 3. Budget expenditures index & 0.928 & 0.933 & 0.933 & 0.933 \\
\hline Total value in the $R F$ & 1.000 & 1.000 & 1.000 & 1.000 \\
\hline $\begin{array}{l}\text { 4. Budget provision level before the } \\
\text { distribution of dotations }\end{array}$ & 0.776 & 0.772 & 0.769 & 0.766 \\
\hline Total value in the $\mathbf{R F}$ & 1.000 & 1.000 & 1.000 & 1.000 \\
\hline $\begin{array}{l}\text { 5. Total dotations for approval, } \\
\text { thousand RUR }\end{array}$ & $5,856,161$ & $7,941,739$ & $4,599,894^{*}$ & $4,275,317^{*}$ \\
\hline Total dotations in the RF, thousand & $514,599,728$ & $614,599,728$ & $430,219,810^{*}$ & $430,219,810^{*}$ \\
\hline $\begin{array}{l}\text { 6. Budget provision level after the } \\
\text { distribution of dotations }\end{array}$ & 0.813 & 0.833 & 0.802 & 0.795 \\
\hline Total value in the $R F$ & 1.000 & 1.000 & 1.000 & 1.000 \\
\hline
\end{tabular}

Note: * for 2018-2019 in 'Total dotations for approval, thousand RUR' and 'Total dotations in the RF, thousand RUR', distribution indicators are taken in the amount of $70 \%$.

Source: compiled by the author based on $[24,25]$.

Table 3 shows that the amount of dotations is formed based on two coefficients - tax potential indices and budget expenditures. The former increased from 0.711 to 0.715 for the entire analyzed period; however, since 2017, it is in gradual decrease: 0.720 in 2017, 0.718 in 2018 and 0.715 in 2019 , which is a factor in increasing the dependence of the budget of the constituent entity of the Russian Federation on inter-budget transfer for equalizing budgetary provision. Budget expenditures index in 2016-2019 increased from 0.928 to
0.933, while in 2017-2019 its value was constant.

The amount of approved dotations increased in 2017 by $35.6 \%$ compared to 2016. In 2018-2019, the amount decreased due to distribution to regional budgets in the amount of $70 \%$ of the total.

Thus, the dynamics in the indicator of estimated budgetary security after the distribution of dotations is of the same nature, namely, in 2017 compared to 2016, this indicator increased by $2.5 \%$, in $2018-2019$ it 
was steadily decreasing: to 0.802 in 2018 and

to 0.795 in 2019.

Table 4. Dotation contributions to the budget of the Kemerovo Oblast - forecast for 20202022.

\begin{tabular}{|c|c|c|c|}
\hline \multirow{2}{*}{ Indicator } & \multicolumn{3}{|c|}{ Year } \\
\hline & 2020 & 2021 & 2022 \\
\hline 1. Resident population, thousand people & 2659.8 & 2659.8 & 2659.8 \\
\hline Total number in the $\mathbf{R F}$ & $146,548.8$ & $146,548.8$ & $146,548.8$ \\
\hline 2. Tax potential index & 0.868 & 0.887 & 0.871 \\
\hline Total value in the RF & 1.000 & $\mathbf{1 . 0 0 0}$ & 1.000 \\
\hline 3. Budget expenditures index & 0.942 & 0.942 & 0.942 \\
\hline Total value in the $\mathrm{RF}$ & 1.000 & 1.000 & 1.000 \\
\hline $\begin{array}{l}\text { 4. Budget provision level before the } \\
\text { distribution of dotations }\end{array}$ & 0.921 & 0.942 & 0.924 \\
\hline Total value in the $\mathrm{RF}$ & $\mathbf{1 , 0 0 0}$ & 1,000 & 1,000 \\
\hline 5. Total dotations for approval, thousand RUR & $3,476,915.8$ & $2,892,983.8$ & - \\
\hline Total dotations in the RF, RUR & $717,866,344.6$ & $511,572,363.7$ & $520,429,426.4$ \\
\hline
\end{tabular}

Note: the population number is taken as of January 1, 2019. In 'Total dotations for approval, thousand RUR' and 'Total dotations in the RF, thousand RUR', the distribution of otations in the amount of $70 \%$ is taken.

Source: compiled by the author based on [18-20, 23].

Table 4 indicates a decrease in dotations in the forecast period. For 2022, dotation deductions for equalizing budgetary provision are not expected. Tax potential index will increase by $0.3 \%$ by 2022 ; budget expenditures will remain constant at 0.942 ; the level of budgetary security by 2022 will amount to 0.924 .

As stated in the guidelines for the regulation of intergovernmental relations at lower levels of the budget system established by the Ministry of Finance of the RF, as well as in accordance with Art. 58 of the Budget Code of the RF, "the subject of the Russian Federation has the right to replace part of the dotation deductions with additional normative on taxes levied" [11]. The size of the tax deduction standard is differentiated; it is determined from the estimated amount of dotations for equalizing the level of budgetary security. 
Let us consider the implementation of

this mechanism in the city budgets of the

Kemerovo region in 2019.

Table 5. Distribution of dotations deductions for equalizing the level of budgetary security of the cities of the Kemerovo Oblast for 2019, thousand RUR

\begin{tabular}{|c|c|c|c|}
\hline \multirow[b]{2}{*}{ City } & \multirow[b]{2}{*}{$\begin{array}{l}\text { Amount of dotations } \\
\text { for equalizing } \\
\text { budgetary provision }\end{array}$} & \multicolumn{2}{|c|}{ including } \\
\hline & & $\begin{array}{l}\text { Part of the dotation, } \\
\text { replaced by an } \\
\text { additional norm for } \\
\text { deductions from } \\
\text { personal income tax }\end{array}$ & $\begin{array}{c}\text { Amount of dotations } \\
\text { provided for in the draft } \\
\text { Law of the Kemerovo } \\
\text { Oblast "On the regional } \\
\text { budget for } 2019 \text { and for } \\
\text { the planning period } \\
2020-2021 \text { " }\end{array}$ \\
\hline Anzhero-Sudzhensk & 765.646 & 230.224 & 535.422 \\
\hline Belovo & 954.368 & 384.594 & 569.774 \\
\hline Berezovsky & 586.072 & 145.774 & 440.298 \\
\hline Kaltan & 331.332 & 90.698 & 240.634 \\
\hline Kemerovo & 4.365 .487 & 1.711 .511 & 2.653 .976 \\
\hline Kiselevsk & 467.089 & 285.827 & 181.262 \\
\hline Leninsk-Kuznetsky & 725.543 & 296.759 & 428.784 \\
\hline Mezhdurechensk & 62.707 & 62.707 & 0 \\
\hline Myski & 108.128 & 108.128 & 0 \\
\hline Novokuznetsk & 4.417 .039 & 1.691 .003 & 2.726 .036 \\
\hline Osinniki & 514.577 & 142.150 & 372.427 \\
\hline Prokopyevsk & 2.032 .217 & 583.944 & 1.448 .273 \\
\hline Polysaevo & 315.549 & 87.575 & 227.974 \\
\hline Taiga & 318.532 & 76.202 & 242.330 \\
\hline Yurga & 831.932 & 248.260 & 583.672 \\
\hline Krasnobrodsky & 35.842 & 35.842 & 0 \\
\hline Total: & 16.832 .060 & 6.181.198 & 10.650 .862 \\
\hline
\end{tabular}

Source: compiled by the author based on $[0,0]$. 
As mentioned above, the largest amount of inter-budget transfers was directed to the budgets of Kemerovo - 4.365.487 thousand RUR, of which $39.2 \%$ was replaced by additional deductions from personal income tax, and of Novokuznetsk 4.417.039 thousand RUR, of which $38.3 \%$ were replaced by tax deductions. In Mezhdurechensk, Myski and Krasnobrodsky, the entire volume of dotations was replaced by deductions from personal income tax. The largest deductions from personal income tax (with the exception of $100 \%$ of the total amount of dotations) can be observed in the budgets of Kiselevsk (61.2\%), LeninskKuznetsky (40.9\%) and Belovo (40.3\%). The smallest deductions are from the budgets of Taiga (23.9\%) and Berezovsky (24.9\%).

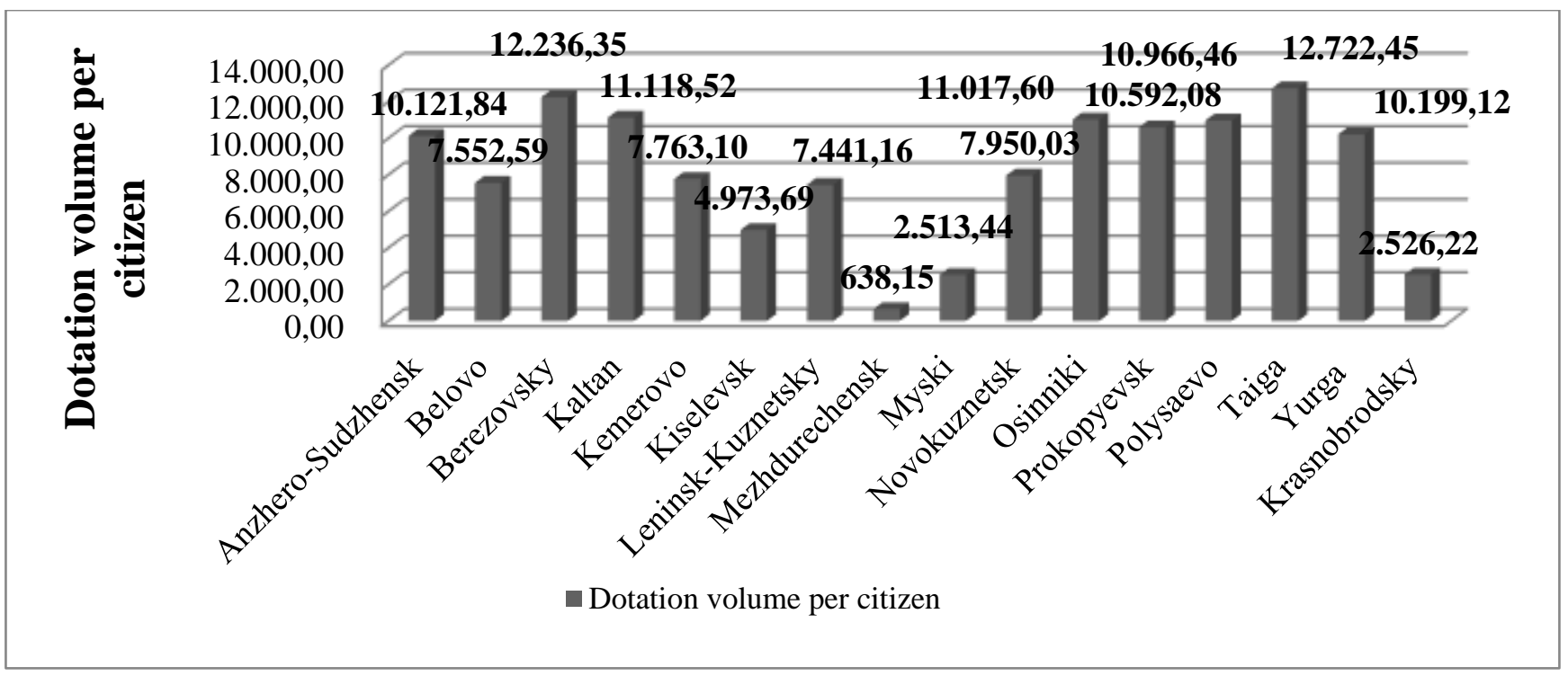

Figure 3. Distribution of the volume of dotations per resident of the cities of the Kemerovo Oblast Source: compiled by the author independently.

Figure 3 shows the distribution of the volume of inter-budget transfer in the form of a dotation per resident of the city. The minimum amount of deductions is on 1 resident of Mezhdurechensk - 638.15 rubles (98.263 thousand people in total). The maximum amount of deductions is on 1 resident of Taiga $-12.722,45$ rubles
(25.037 thousand people in total). In the cities where budgets account for the largest volumes of dotations, namely, Kemerovo and Novokuznetsk, the amount is 7763.10 rubles $(562.338$ thousand people in total) and 7950.03 rubles (555.600 thousand people in total). 
The average amount of dotation per resident is 8014.06 RUR. In 7 cities - Belovo, Kemerovo, Kiselevsk, Leninsk-Kuznetsky, Mezhdurechensk, Myski, and Novokuznetsk, as well as in Krasnobrodsky, the amount is below this level. This distribution is due to the fact that the level of budgetary provision before leveling in these cities is quite high, namely: Belovo - 0.9887; Kemerovo-0.9401; Kiselevsk - 1.3167; Leninsk-Kuznetsky _ $\quad$ - 0.9556 ; Mezhdurechensk - 2.894; Myski 2.4740; Novokuznetsk $\quad-\quad 0.9168$; Krasnobrodsky -2.2057 . In the eight remaining cities, the level of budgetary provision before leveling does not exceed 0.8000: Anzhero-Sudzhensk 0.6057; Berezovsky - 0.4675; Kaltan 0.6771; Osinniki - 0.4791; Prokopyevsk - 0.5343; Polysaevo - 0.7669; Taiga 0.4123; Yurga - 0.6017 .

Thus, the Kemerovo Oblast ranks third in terms of estimated budgetary security at the Siberian federal level, which is a positive factor in the development of the region. At the same time, the percentage of tax revenues in the local budgets does not exceed the limit taken in Russia as a whole. According to information provided by the Main Financial Department of the
Kemerovo Oblast, by 2021, revenues from:

1) corporate income tax will decrease by about $11.5 \%$;

2) personal income tax will increase by $14.4 \%$;

3) excise taxes will increase by $47 \%$;

4) single tax according to the simplified taxation system will increase by $8.2 \%$;

5) property tax of organizations will be reduced by $6 \%$;

6) transport tax will increase by $5.6 \%$

7) tax on the extraction of minerals will be reduced by $10.8 \%$ [3]

In general, by 2021 tax revenues will increase by $2.3 \%$ (from 112.343,2 thousand RUR in 2019 to $114.918,1$ thousand RUR in 2021). However, these revenues will not be enough; a need for budgeting through inter-budget transfers will remain, which means that the existing practice of inter-budget relations contributes to maintaining the dependence of the regional budget on the federal budget. At the same time, gratuitous receipts of a general nature to budgets of lower levels in the structure of expenditures of the regional budget by 2021 will decrease by $50.4 \%$ (from 
$18.755,1$ thousand RUR in 2019 up to 9.300,2 thousand RUR in 2021).

\section{Conclusion}

The present research reveals the need for reforming the intergovernmental relations, and the necessity to introduce forward-looking financial planning into the budget process is undeniable, since financial forecasts for the medium term are developed in almost all countries. The need to plan budgetary processes is due to the need to determine the financial and economic capabilities of the state at present and in the near future, which has a significant impact on investment processes development and, at the same time, on the conditions for the formation and implementation of budgetary policies aimed at long-term strategic social and economic goals for the country.

The main task of improving interbudgetary relations in the Russian Federation is forming an effective mechanism to distribute budget revenue sources between authorities in order to implement the expenditure powers of the state, which are associated with political and socio-economic development of the country as a whole, of its subjects and municipalities.

The analysis of the execution of the regional budget and the budgets of municipalities of the Kemerovo Oblast showed that in the budgets of lower levels, the revenue should be generated from own resources of the subject of the RF. For this, the existing practice of budget revenue generation should be reviewed, namely:

1) to reform the methods of distribution of tax deductions between the budgets of the budget system of the Russian Federation. A structural analysis of these deductions indicates that the share of basic income-generating taxes is falling. Thus, the standards for deductions should be reviewed;

2) to reform the mechanisms of control of local executive bodies over the accumulation and distribution of funds in local budgets.

The implementation of these measures will allow bringing the modern concept of inter-budgetary relations to a qualitatively higher level.

\section{References}

The main directions of the budget, tax and customs tariff policy for 2019 and for the planning period 2020-2021 
(approved by the Ministry of Finance of Russia). Legal system Consultant Plus. URL:

http://www.consultant.ru/document/con s_doc_LAW_308390/95012fad365f2e2 451d70496bf2cc4b592d9975b/

(accessed: 01/23/2020).

Administration of Kemerovo. Official site. URL: https://kemerovo.ru/sferydeyatelnosti/ekonomika/byudzhet-dlyagrazhdan/ (accessed: 12/05/19).

The budget for citizens of the Kemerovo Oblast for 2019 and for the planning period 2020 and 2021. Main financial department of the Kemerovo Oblast. Official site. URL: https://www.ofukem.ru/upload/iblock/d b9/bg2019_2021.pdf (accessed: 12/17/19).

The budget code of the Russian Federation. Legal system Consultant Plus.

URL: http://www.consultant.ru/cons/cgi/onlin e.cgi?req $=$ doc $\&$ base $=L A W \& n=336780$ $\&$ fld $=134 \& \mathrm{dst}=5631.0 \& \mathrm{rnd}=0.6846264$ 660066448\#038738256302925134

(accessed: 12/07/19).

Klimanova V.V. Foreign experience of innovations in intergovernmental relations: selection of scientific works. Moscow, 2009. (accessed: 01/23/2020).
Information on the results of monitoring the implementation of local budgets and inter-budget relations in the constituent entities of the Russian Federation at the regional and municipal levels for 2015. Ministry of Finance of the Russian Federation. Official site. URL: https://www.minfin.ru/common/upload/ library/2016/07/main/Rezultaty_proved eniya_monitoringa_mestnykh_budzheto v_za_2015_god.pdf (access date: $12 / 05 / 19)$.

Information on the results of monitoring the implementation of local budgets and inter-budget relations in the constituent entities of the Russian Federation at the regional and municipal levels for 2016. Ministry of Finance of the Russian Federation. Official site. URL: https://www.minfin.ru/common/upload/ library/2017/06/main/Rezultaty_proved eniya_monitoringa_mestnykh_budzheto v_za_2016_god-versiya_28.06.2017.pdf (access date: 12/05/19).

Information on the results of monitoring the implementation of local budgets and inter-budget relations in the constituent entities of the Russian Federation at the regional and municipal levels for 2017. Ministry of Finance of the Russian Federation. Official site. URL:: https://www.minfin.ru/ru/perfomance/re 
gions/monitoring_results/Monitoring_lo cal/results/?id_57=122980-

informatsiya_o_rezultatakh_provedeniy a_monitoringa_ispolneniya_mestnykh_ byudzhetov_i_mezhbyudzhetnykh_otno shenii_v_sube (access date: 05/12/19).

Information on the results of monitoring the implementation of local budgets and inter-budget relations in the constituent entities of the Russian Federation at the regional and municipal levels for 2018. Ministry of Finance of the Russian Federation. Official site. URL: https://www.minfin.ru/common/upload/ library/2019/08/main/Rezultaty_proved eniya_monitoringa_mestnykh_budzheto v_za_2018_god.pdf (access date: 05/12/19).

Kulkova, V.Yu. Formation of a model of intergovernmental relations in the Russian Federation: stages, trends, problems. Bulletin of Kazan Technological University. 2006. URL: https://cyberleninka.ru/article/n/formiro vanie-modeli-mezhbyudzhetnyhotnosheniy-v-rossiyskoy-federatsiietapy-tendentsii-problemy/viewer (access date: 23/01/2020).

Guidelines for the regulation of interbudgetary relations at the regional and municipal levels. Ministry of Finance of the Russian Federation.
716

Official site. URL: https://www.minfin.ru/common/gen_ht $\mathrm{ml} /$ ?id=61361\&fld=FILE_MAIN\#_Toc 399889516 (access date: 10/12/19). Morozova, E.A., Shakhvorostov, I.S. Models of the organization of intergovernmental relations in foreign countries and the possibility of their use in the Russian Federation. Issues of economics and law. 2012. URL: https://law-

journal.ru/files/pdf/201206/201206_162 .pdf (accessed: 01/23/2020).

Report on the execution of the consolidated budget of the subject of the Russian Federation. Main financial department of the Kemerovo Oblast. Official site. URL: https://www.ofukem.ru/reports/annualreports/2014 (access date: 12/04/19). Report on the execution of the consolidated budget of the subject of the Russian Federation and the budget of the territorial state extra-budgetary fund as of January 1, 2016. Main financial department of the Kemerovo Oblast. Official site. URL: https://www.ofukem.ru/reports/annualreports/2015/ (date of access: 12/17/19). Report on the execution of the consolidated budget of the subject of the Russian Federation and the budget of the 
territorial state extra-budgetary fund as of January 1, 2017. Main financial department of the Kemerovo Oblast. Official site. URL: https://www.ofukem.ru/reports/annualreports/2016/ (date of access: 12/17/19). - Report on the execution of the consolidated budget of the subject of the Russian Federation and the budget of the territorial state extra-budgetary fund as of January 1, 2018. Main financial department of the Kemerovo Oblast. Official site. URL: https://www.ofukem.ru/reports/annualreports/2017/ (access date: 12/17/19). Report on the execution of the consolidated budget of the subject of the Russian Federation and the budget of the territorial state extra-budgetary fund as of January 1, 2019. Main financial department of the Kemerovo Oblast. Official site. URL: https://www.ofukem.ru/reports/annualreports/2018/ (date of access: 12/17/19). Report on the volume of financial resources of the state program of the Kemerovo Oblast "Management of public finances of the Kuzbass" for 2018. Main financial department of the Kemerovo Oblast. Official site. URL: https://www.ofukem.ru/activity/budget- execution-and-analytical-data/2018/ (accessed date: 12/07/19).

Report on the amount of financial resources of the state program of the Kemerovo Oblast "Management of public finances of the Kuzbass" for 2017. Main financial department of the Kemerovo Oblast. Official site. URL: https://www.ofukem.ru/activity/budgetexecution-and-analytical-data/2017/ (accessed: 12/07/19).

Report on the volume of financial resources of the state program of the Kemerovo Oblast "Management of public finances of the Kuzbass" for 2017. Main financial department of the Kemerovo Oblast. Official site. URL: https://www.ofukem.ru/activity/budgetexecution-and-analytical-data/2016/ (accessed: 12/07/19).

The calculation of the distribution of subsidies for equalizing the budgetary provision of municipal districts (urban districts) for 2019. Main financial department of the Kemerovo Oblast. Official site. URL: https://www.ofukem.ru/activity/intergov ernmentalrelations $/ \mathrm{ID}=11497 /$ ?sphrase_id=8732 (accessed: 12/07/19).

The calculation of the distribution of subsidies for equalizing the budgetary 
provision of municipal districts (urban districts) for 2020 and for the planning period 2021-2022. Main financial department of the Kemerovo Oblast. Official site. URL: https://www.ofukem.ru/activity/intergov ernmental-relations/ (accessed: 12/07/19).

The Calculation of the distribution of subsidies for equalizing budgetary provision between the constituent entities of the Russian Federation for 2018 and the planning period 2019-2020. Ministry of Finance of the Russian Federation.

URL: https://www.minfin.ru/ru/document/?id _4=119735-

raschet_raspredeleniya_dotatsii_na_vyr avnivanie_byudzhetnoi_obespechennost i_mezhdu_subektami_rossiiskoi_federat sii_na_2018_god_i_planovyi_period_20 19_i_2020_godov (accessed: 07/12/19). The results of the distribution of subsidies for equalizing the budgetary provision of the constituent entities of the Russian Federation for 2016, the Ministry of Finance of the Russian Federation. Official site. URL: https://www.minfin.ru/common/upload/ library/2015/10/main/ffpr_2016.pdf (access date: 12/07/19).
The results of the distribution of subsidies for equalizing the budgetary provision of the constituent entities of the Russian Federation for 2017-2019. Ministry of Finance of the Russian Federation. Official site. URL: https://www.minfin.ru/common/upload/ library/2016/12/main/FFPR_20172019.pdf (access date: 12/07/19).

Sanoh A. Rainfall Shocks, Local Revenues, and Intergovernmental Transfer in Mali. URL: https://doi.org/10.1016/j.worlddev.2014 .08.022 (accessed: 15/10/2019).

Bird R.M., Smart M. Intergovernmental Fiscal Transfers: International Lessons for Developing Countries. URL: https://doi.org/10.1016/S0305-

750X(02)00016-5 (accessed: 25/11/2019).

Masaki T. The impact of intergovernmental transfers on local revenue generation in Sub-Saharan Africa: Evidence from Tanzania. URL: https://doi.org/10.1016/j.worlddev.2018 $\underline{.01 .026}$ (accessed: 20/12/2019) 